\title{
MODELING OF WATER REMOVAL IN DIRECT-CHILL CASTING OF ALUMINUM-ALLOY BILLETS
}

\section{MODELIRANJE OMEJEVANJA NEPOSREDNEGA HLAJENJA Z VODO MED VERTIKALNIMI KONTI LITJEM GREDIC IZ Al-ZLITIN}

\author{
Amirhossein Meysami ${ }^{1}$, Shahin Mahmoudi ${ }^{2}$, Mahmoud Hajisafari ${ }^{2}$ \\ ${ }^{1}$ Golpayegan University of Technology (GUT), Metallurgy and Materials Engineering Department, Golpayegan, Iran \\ Islamic Azad University, Yazd Branch, Department of Metallurgy and Materials Engineering, Yazd, Iran \\ meysami@gut.ac.ir \\ Prejem rokopisa - received: 2017-05-13; sprejem za objavo - accepted for publication: 2017-07-28
}

\author{
doi:10.17222/mit.2017.054
}

\begin{abstract}
Water removal is one of the methods for preventing hot tears in the production of defect-free aluminum billets. Using this method, the cooling rate near the bottom of the sump is reduced, and as a result, the possibility of creating hot tears at the final stages of solidification can be minimized. The temperature of the solid crust can be increased and the residual stresses in a casting can be minimized. A system of direct-chill casting was simulated and the influence of effective parameters, like the casting speed, was investigated. The casting speed and the position of water removal were the most effective parameters. Their optimum amounts for various diameters of the aluminum alloy were critical for the accumulated residual stresses and casting condition. The optimum conditions such as the minimum sump depth, mushy-zone thickness, minimum radial thermal gradient and strain rate near the bottom of the sump were predicted by this simulation.

Keywords: casting, aluminum alloy, hot crack
\end{abstract}

V pričujočem članku avtorji obravnavajo vertikalno kontinuirno (konti) litje gredic na osnovi Al zlitin z direktnim vodnim hlajenjem (angl.: Direct-Chill casting; DC). Primerna kontrola ohlajanja oz. omejevanje pretoka vode je ena izmed metod, ki preprečuje nastanek vročih razpok in drugih livarskih napak med konti litjem gredic. Pri tej metodi zmanjšamo hitrost pretoka vode oz. ohlajanja na dnu zbiralnika in posledično zmanjšamo na minimum tudi možnost tvorbe vročih razpok $\mathrm{v}$ zadnji fazi strjevanja. Na ta način je temperatura strjenega dela ingota (gredice) oz. trdne skorje višja in zaostale napetosti v gredici, nastale med litjem so manjše. Avtorji prispevka so izvedli simulacijo procesa DC litja in ugotavljali vpliv posameznih procesnih parametrov. Na proces litja sta najbolj vplivala hitrost litja in mesto odstranjevanja vode. Optimalne vrednosti teh dveh parametrov pri litju gredic različnih premerov so odoločilno vplivale na velikost zaostalih napetosti in ostale pogoje litja Al zlitin. S to simulacijo so avtorji določili optimalne pogoje litja, kot so minimalna globina vodnega zbiralnika, debelina testaste (kašaste) cone, najmanjši radialni termični gradient in hitrost deformacije blizu dna zbiralnika.

Ključne besede: konti litje gredic, aluminijeve zlitine, vroče razpoke

\section{INTRODUCTION}

One of the major defects in the production of highstrength aluminum (Al) billets are hot tears in the center of a billet. Several efforts have been made to eliminate these drawbacks and different methods have been used. One of the most important ways of producing highstrength aluminum billets with large diameters in different industrial plants is the control of the ingot cooling rate, based on the removal of the water from the ingot surface, achieved by applying the water removal below the mold bottom. Using this method, the cooling rate during the final stages of the solidification in the billet center is decreased and the possibility of hot tearing during the final stages is significantly reduced. Moreover, due to the latent heat released during the solidification, the temperature of the formed solid crust is increased, also causing the removal of the residual stresses from the billet.

Considering this approach, P. P. Zeigler ${ }^{1}$ presented a plan, with which full cooling of a billet with water during the secondary cooling could be prevented. With this method, the water streaming on a billet surface will be removed using an air jet in the opposite direction. The air-jet distance changes with a change in the chemical composition of a billet, the cooling rate in the secondary zone of the billet and the casting velocity. The amount of the heating output from the surface of a billet should be controlled so that the temperature of the billet surface after the water removal should not be less than $150{ }^{\circ} \mathrm{C}$ and it is preferably between $200{ }^{\circ} \mathrm{C}$ and $340{ }^{\circ} \mathrm{C}$. It should be noted that the billets produced with this process have large diameters and need the annealing process to be used during the other stages; the desired temperature of annealing is about $315-430{ }^{\circ} \mathrm{C}$. If the water from the surface of a billet is removed, due to an increase in the temperature of the solid layer, the annealing processes are largely completed and the common annealing heat-treatment process can be greatly reduced.

There are also other researchers who used this method; with the T. C. Zinniger method ${ }^{2}$, water removal is done using a rubber ring, placed at a certain distance 


\section{MATERIALI IN TEHNOLOGIJE/MATERIALS AND TECHNOLOGY (1967-2017) - 50 LET/50 YEARS}

\section{A. H. MEYSAMI et al.: MODELING OF WATER REMOVAL IN DIRECT-CHILL CASTING OF ALUMINUM-ALLOY BILLETS}

from the mold bottom. Another method was proposed by E. W. Reeves et al. ${ }^{3}$; they used a water jet in the direction opposite to the water flow on the surface, at a certain angle and velocity, causing the removal of the streaming water from the surface. E. Gervais et al. ${ }^{4}$ provided another method for water removal. In their method, the water is removed from the surface of a billet with a tool called Waiper.

C. Devadas and J. F. Grandfield ${ }^{5}$ carried out a general review of modeling a DC aluminum casting. In addition, D. G. Eskin ${ }^{6}$ reviewed and fully discussed the metallurgy of the direct-chill-casting process. V. Schneider and E. K. Jensen ${ }^{7}$ considered the cracking at the start of billet casting and recognized the depth of the sump as the criterion for hot tearing. According to this criterion, the possibility of hot tearing is increased due to the increasing sump depth, and this assumption is similar to the new theories of hot tearing. ${ }^{89}$ By increasing the sump depth, the thickness of the mushy zone in the center of a billet will also increase. As a result, the possibility of melt feeding is reduced and the probability of hot cracking is increased.

In the past decades, several methods were employed to produce all the aluminum alloys using the process of DC casting. However, in the production of series $2 \mathrm{xxx}$ and $7 \times x x$ of aluminum alloys, having a large solidification range, there are both hot and cold cracks. ${ }^{9}$ Hot tearing occurs as long as there is a lack of feeding during the solidification. Several studies suggested that by increasing the casting velocity, the possibility of hot tearing will also increase and this defect occurs mostly in the center of a billet. ${ }^{10-11} \mathrm{M}$. Lalpoor et al. ${ }^{12}$ showed that in steady-state conditions, large compressive stresses are formed close to the surface of a billet in the circumferential direction, while in the center, tensile stresses act in all directions. In a research carried out by Y. Wang, ${ }^{13}$ the removal of water from slabs made of the 7075 aluminum was studied.

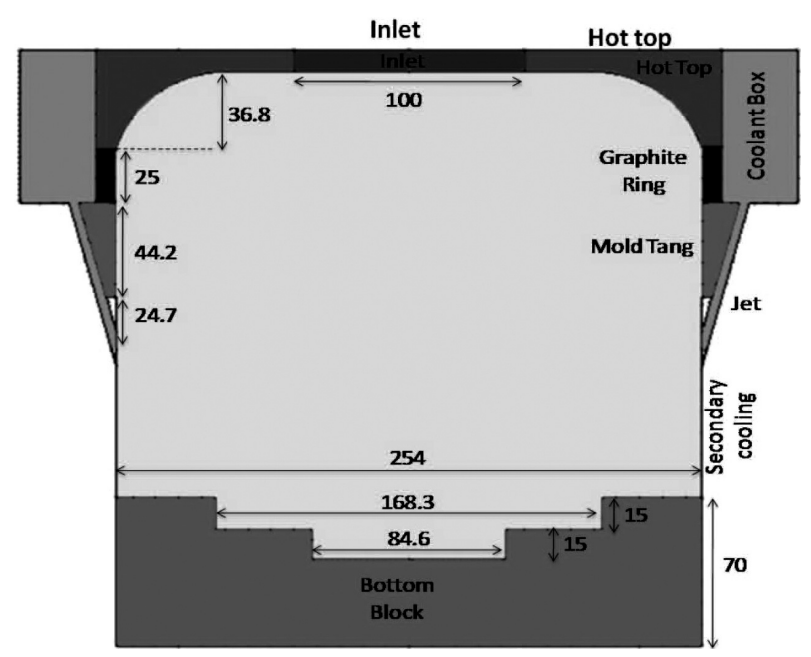

Figure 1: Schematic of DC-casting mold system used in this study for a $254 \mathrm{~mm}$ billet
In this research, the temperature distribution for 7075 $\mathrm{Al}$ ingots was calculated and the optimum condition for a water-restricted panel and the casting velocity was determined. This is a new method and no research has recently been done in this field.

\section{MATERIALS AND METHODS}

One important factor in the process of modeling is to determine the exact geometry of the flow field or, in other words, the range of the melt flow. A schematic design of a DC-casting system including different parts and dimensions of a $254 \mathrm{~mm}$ billet is shown in Figure $\mathbf{1}$. In Figure 2, a computational grid used in the domain of casting is shown for a $762 \mathrm{~mm}$ billet. Physical and thermal properties used for modeling the DC casting of 2024 aluminum-alloy billets vary with the temperature as shown in Table 1.

Table 1: Thermophysical properties of 2024 aluminum alloy used for the modeling

\begin{tabular}{|c|c|c|c|c|c|}
\hline $\begin{array}{c}\text { Viscosity } \\
(\mathrm{mPa})\end{array}$ & $\begin{array}{c}\text { Density } \\
\left.\mathrm{kg} / \mathrm{m}^{3}\right)\end{array}$ & $\begin{array}{c}\text { Heat } \\
\text { capacity } \\
(\mathrm{J} / \mathrm{kg})\end{array}$ & $\begin{array}{c}\text { Enthalpy } \\
(\mathrm{J} / \mathrm{g})\end{array}$ & $\begin{array}{c}\text { Conduc- } \\
\text { tivity } \\
\left(\mathrm{W} / \mathrm{m}^{2} \mathrm{~K}\right)\end{array}$ & $\begin{array}{c}\text { Tempe- } \\
\text { rature } \\
\left({ }^{\circ} \mathrm{C}\right)\end{array}$ \\
\hline- & 2785 & 0.85 & 0 & 175 & 25 \\
\hline- & 2779 & 0.9 & 66 & 185 & 100 \\
\hline- & 2750 & 0.95 & 159 & 193 & 200 \\
\hline
\end{tabular}

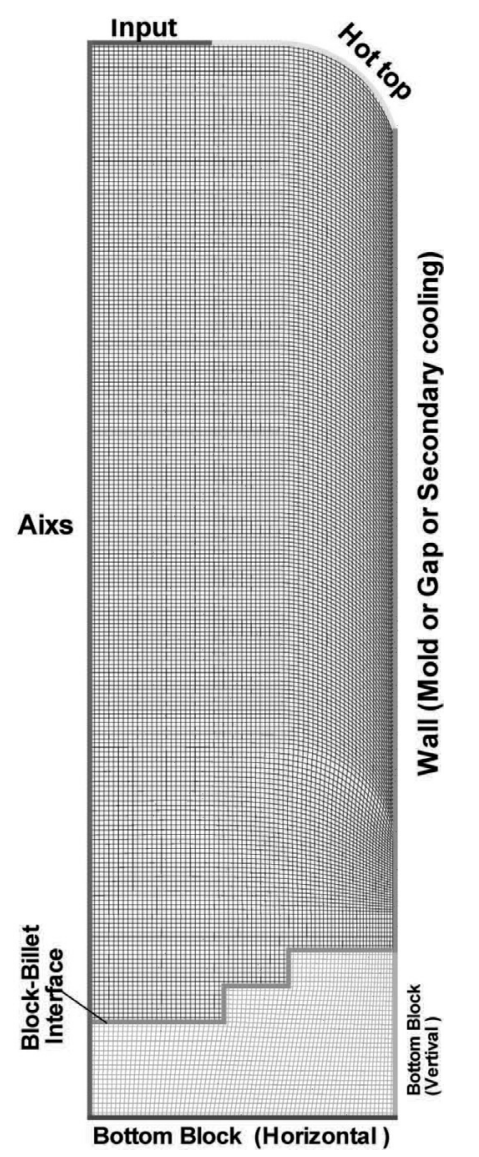

Figure 2: Computational grid used for modeling a $762 \mathrm{~mm}$ billet 
A. H. MEYSAMI et al.: MODELING OF WATER REMOVAL IN DIRECT-CHILL CASTING OF ALUMINUM-ALLOY BILLETS

\begin{tabular}{|c|c|c|c|c|c|}
\hline- & 2730 & 0.97 & 255 & 193 & 300 \\
\hline- & 2707 & 0.10 & 353 & 190 & 400 \\
\hline- & 2683 & 0.18 & 457 & 188 & 500 \\
\hline- & 2674 & 1.10 & 566 & 188 & 538 \\
\hline 1.3 & 2500 & 1.14 & 970 & 85 & 632 \\
\hline 1.2 & 2480 & 1.14 & 1048 & 84 & 700 \\
\hline 1.1 & 2452 & 1.14 & 1162 & 175 & 800 \\
\hline
\end{tabular}

\section{GOVERNING EQUATIONS AND BOUNDARY CONDITIONS}

In order to determine the velocity vectors of this model, the continuity and momentum equations for an incompressible Newtonian fluid in two-dimensional cylindrical coordinates were employed. In order to predict the temperature distribution, by considering the solidification, the energy equation was solved.

Continuity equation (1):

$$
\frac{1}{r} \frac{\partial}{\partial r}=\left(r v_{\mathrm{r}}+\frac{\partial}{\partial z}\left(v_{z}\right)=0\right.
$$

Momentum equation (2) in the $z$ direction:

$$
\begin{aligned}
& \rho\left(\frac{\partial v_{z}}{\partial t}+v_{r} \frac{\partial v_{z}}{\partial r}+v_{z} \frac{\partial v_{z}}{\partial z}\right)= \\
& =\left[\frac{1}{r} \frac{\partial}{\partial r}\left(r \mu \frac{\partial v_{r}}{\partial r}\right)+\frac{\partial}{\partial z}\left(\mu \frac{\partial v_{z}}{\partial z}\right)\right]-\frac{\partial P}{\partial z}+\alpha\left(T-T_{0}\right) \rho g_{r}+S c
\end{aligned}
$$

Momentum equation (3) in the $r$ direction:

$$
\begin{aligned}
& \rho\left(\frac{\partial v_{r}}{\partial t}+v_{r} \frac{\partial v_{r}}{\partial r}+v_{z} \frac{\partial v_{r}}{\partial z}\right)= \\
& =\left[\frac{\partial}{\partial r}\left(\frac{1}{r} \mu \frac{\partial}{\partial r}\left(r v_{r}\right)\right)+\frac{\partial}{\partial z}\left(\mu \frac{\partial v_{r}}{\partial z}\right)\right]-\frac{\partial P}{\partial r}+\rho g_{r}+S
\end{aligned}
$$

Energy equation (4):

$$
\begin{aligned}
& \rho\left(\frac{\partial H}{\partial t}+\frac{\partial\left(\rho v_{z} H\right)}{\partial z}+\frac{1}{r} \frac{\partial\left(r v_{r} H\right)}{\partial r}\right)= \\
& =\frac{1}{r} \frac{\partial}{\partial r}\left(k r \frac{\partial T}{\partial r}\right)+\frac{\partial}{\partial z}\left(k \frac{\partial T}{\partial z}\right)
\end{aligned}
$$

In the above equations, $\alpha$ is the coefficient of the thermal expansion, which is the driving force of the thermal buoyancy in the liquid-pool area and Darcy's law is also used to model the flow in the mushy zone: ${ }^{14}$

$$
u=\frac{1}{K_{\mathrm{D}}}\left(\frac{\partial P}{\partial z}+\rho g_{z}\right)
$$

In equation $(5), K_{\mathrm{D}}$ in the mushy zone is the function of the molten volume fraction.

In the present model, it is assumed that the velocity on all solid surfaces is equal to the casting velocity. For the output (solidified ingots), the velocity is equal to the casting velocity and it is assumed that the molten material enters at a uniform velocity from the top of the computational domain (the flow inlet).
In the DC-casting process, the molten thermal energy is extracted in two regions, primary cooling and secondary cooling. Primary cooling occurs inside the mold zone and below the mold. Secondary cooling is initiated by the water flow on the surface of the billet, and it also has two impingement and streaming zones where the impingement zone is the location of the first water contact, at which the cooling rate is higher than in the streaming zone because the kinetic energy of the inlet water is removed and water moves based on the gravitational force. The boundary condition of the energy equation for the surface of the billet can be summarized as shown in Table 2.

Equations (1) to (4) were discretized with the finite volume method (FVM) in a cylindrical coordination. A first-order, upwind, differencing, implicit approach was used and the discretized equations were solved with the TDMA algorithm using an iterative method. Figure 3 shows the finite volume meshing on the Cartesian coordinates. The program was solved with the Ansys Fluent V12 software.

Table 2: Heat-transfer coefficient of primary and secondary cooling zones in the model of a DC-cast billet

\begin{tabular}{|l|c|c|}
\hline \multicolumn{1}{|c|}{ Cooling region } & $H_{\text {cooling }}$ & $T_{\text {cooling }}(\mathrm{K})$ \\
\hline Hot top & 0 & - \\
\hline Mold (primary cooling) & \\
\hline Melt contact & 2000 & 320 \\
\hline Air gap & 50 & 320 \\
\hline Secondary cooling & 50 & 320 \\
\hline Air gap & 20000 & 320 \\
\hline Impingement zone & 10000 & 320 \\
\hline Streaming zone &
\end{tabular}

\section{RESULTS AND DISCUSSION}

\subsection{Model validation}

Before providing the results of the present study, the results of the current-model validation needed to be provided to ensure a proper performance of this computational model. The validation of the present model was compared with the results of C. J. Vreeman et al. ${ }^{15}$ A pool profile was obtained by C. J. Vreeman using a sudden addition of a molten material with a grain refiner to the hot top of the caster during the steady-state casting of a $450 \mathrm{~mm}$ billet. Figure $\mathbf{3 b}$ shows a macrograph of the pool in a grain-refined billet. In this macrograph, the etched lines represent the solidus interface and the transition between the rigid, packed solid and the slurry. Figure 3a shows the results of the simulation presenting a computational model with the work of Vreeman ${ }^{15}$ (alloy Al-6wt\%Cu with a casting velocity of $6 \mathrm{~cm} / \mathrm{min}$ ) including liquid fraction contours and velocity vectors. The profile of the pool obtained with an etched macrograph (Figure 3b) of the grain-refined billet was compared with the predictions (Figure 4a), with the current calculation and Vreeman's computational model. ${ }^{15}$ As 

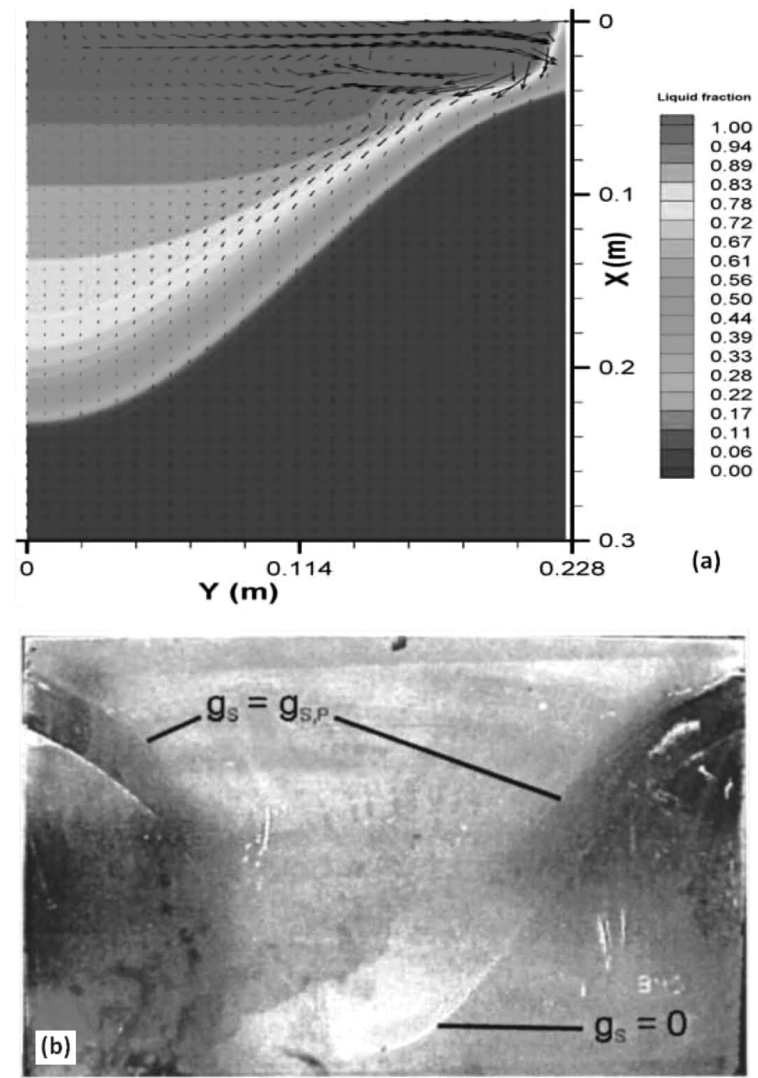

Figure 3: a) Fluid fraction contours with velocity vectors resulting from the current computational model of a casting system is validated, b) macrograph of the pool profile in a grain-refined billet ${ }^{15}$
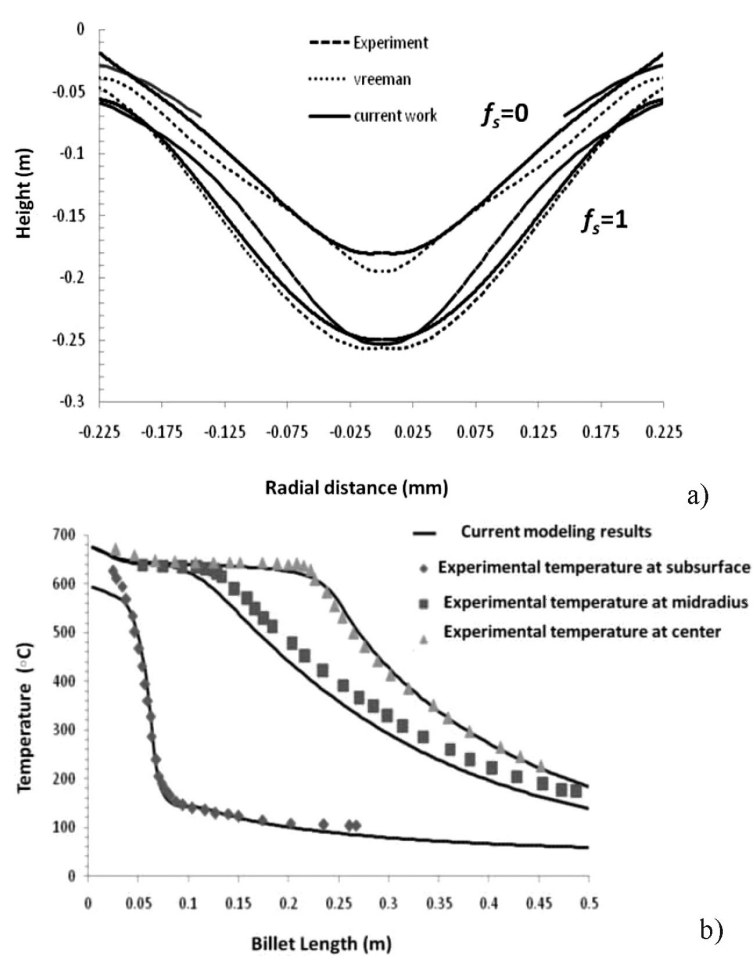

Figure 4: Comparing the results of prediction: a) profile of the pool, b) profile of the temperature variation at three points: surface, middle part and center of a billet ${ }^{15}$

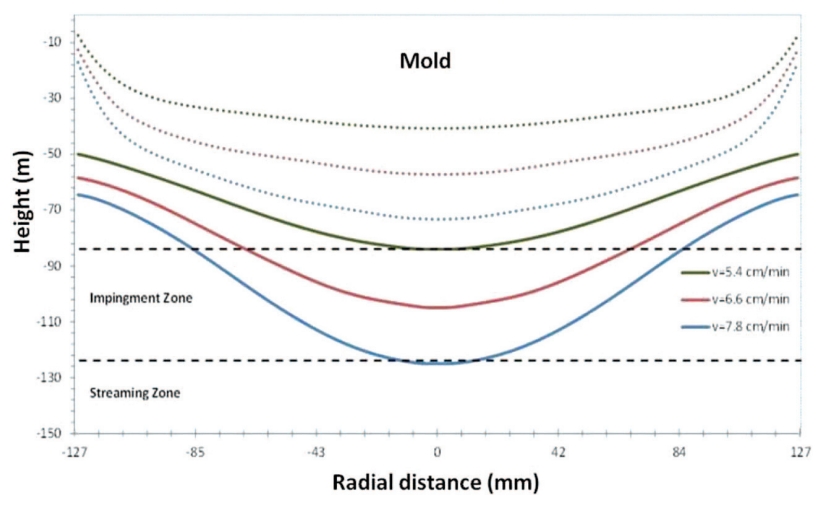

Figure 5: Prediction of the pool profile in the steady-state condition for a $254 \mathrm{~mm}$ billet at three casting velocities (5.4, 6.6 and 7.8) $\mathrm{cm} / \mathrm{min}$ so that dotted lines indicate fluid fraction 0.7 (start of mushy zone) and bold lines are the zero fluid fraction (pool profile)

shown, both models are in good agreement with the results of the measurement done when predicting the pool depth. A comparison of the vertical temperature profiles from the experiments by Vreeman and the current computational model is shown in Figure 4b. At all three radial positions (surface, middle part and center), the temperature decreases as a result of the conduction toward the chill, and in the middle part and the center of the solidification range, the steep temperature variation is reduced. As shown in this case, in the three points, especially in the center, there is good agreement between the experiment and the modeling result.

\subsection{Computational model results}

In the DC-casting process, one of the issues that represents the criterion for the quality of a billet and prevents hot tearing is the pool depth. In Figure 5, the pool and mushy profiles are shown for three casting velocities of $(5.4,6.6$ and 7.8$) \mathrm{cm} / \mathrm{min}$ for the $254 \mathrm{~mm}$ 2024 billet. As shown, if the casting velocity increases, the pool depth is uniformly increased. On the other hand, by increasing the casting velocity, the starting place of the solid crust (at the mold wall) and the pool bottom (at

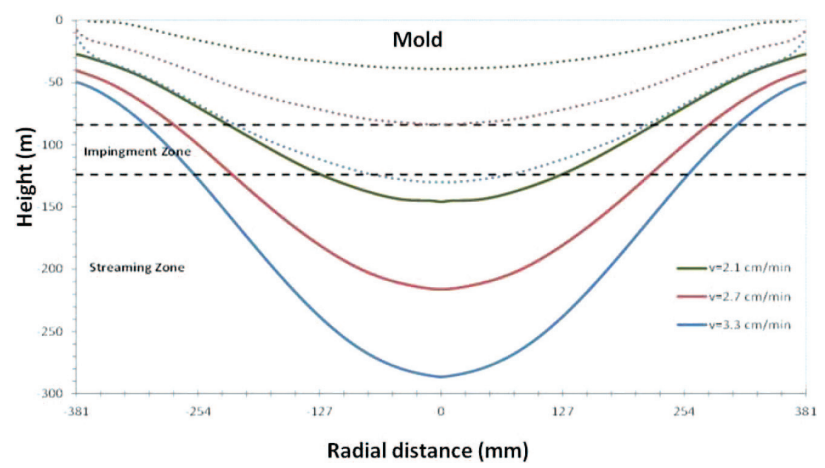

Figure 6: Prediction of the pool profile in the steady-state condition for a $762 \mathrm{~mm}$ billet at three casting velocities (2.1, 2.7 and 3.3) $\mathrm{cm} / \mathrm{min}$ so that dotted lines indicate fluid fraction 0.7 (start of mushy zone) and bold lines are the zero fluid fraction (pool profile) 
the center) are transferred to the lower places of the mold that allow more movement. Another parameter that can increase the pool depth is an increase in the cooling in the secondary zone. Figure 6 shows the pool and mushy profiles at three casting velocities for the $762 \mathrm{~mm} 2024$ billet. As shown, there is a similarity with the $254 \mathrm{~mm}$ billet: if the casting velocity increases, the pool depth will be increased. In this billet, the diameter of the pool depth and the mushy thickness are significantly larger than those of the $254 \mathrm{~mm}$ billet, which makes it more sensitive to hot tearing. In order to prevent hot tearing, the pool depth and strain rate should be kept at minimum and optimum amounts.

\subsection{Water removal}

In this section, the method of water removal based on the temperature distribution of the 2024 billet is investigated. In order to have a more accurate and quantitative evaluation of the pool depth by the water-removal panel, Figure 7 is provided. In this figure, the changes in the pool depth and the thickness of the mushy zone are plotted for the locations of the water-removal panel. In this figure, guidelines of $0.5 R, 0.6 R$ and $0.7 R(R$ is the radius of the billet) are used. The purpose of drawing these guidelines is to present the condition, under which the billet can be cast without any risk of hot tearing.

According to F. Grandfield's research, ${ }^{16}$ the $0.7 R$ criterion is obtained with this experiment and this diagram. It is considered that if the $0.5 R$ criterion can be used for the pool depth of the $762 \mathrm{~mm}$ billet for more safety, then the casting velocity of $2.4 \mathrm{~cm} / \mathrm{min}$ would not be suitable and it is better to use the casting velocity of 2.1 or $1.8 \mathrm{~cm} / \mathrm{min}$. At the casting velocity of $2.1 \mathrm{~cm} / \mathrm{min}$, with the panel distance being longer than $10 \mathrm{~cm}$ (from the bottom of the mold), the pool depth is good; at the casting velocity of $1.8 \mathrm{~cm} / \mathrm{min}$, with the panel distance being longer than $6 \mathrm{~cm}$, the pool depth is suitable. If the casting velocity of $2.1 \mathrm{~cm} / \mathrm{min}$ and the panel distance of $10 \mathrm{~cm}$ are selected as a suitable condition, then this distance can also be chosen for the velocity of $1.8 \mathrm{~cm} / \mathrm{min}$, with the removal place of $7 \mathrm{~cm}$, to decrease the mushy thickness in the pool depth. This velocity is better than

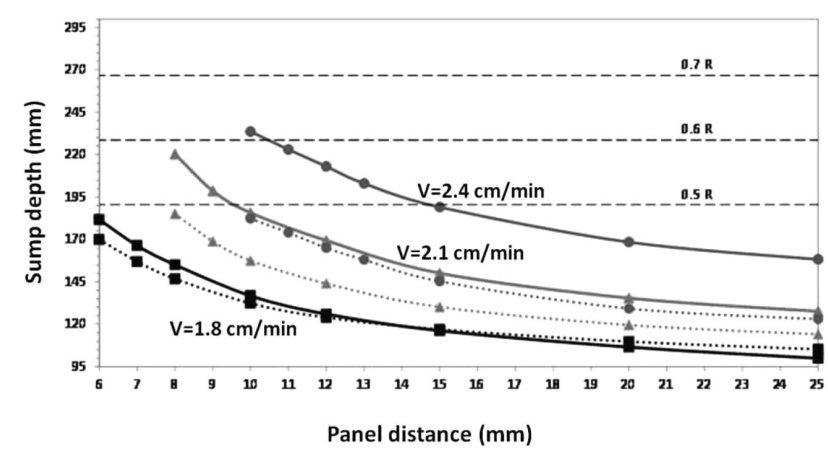

Figure 7: Variations in the pool depth and mushy thickness for the panel place of the $762 \mathrm{~mm}$ billet at various casting velocities

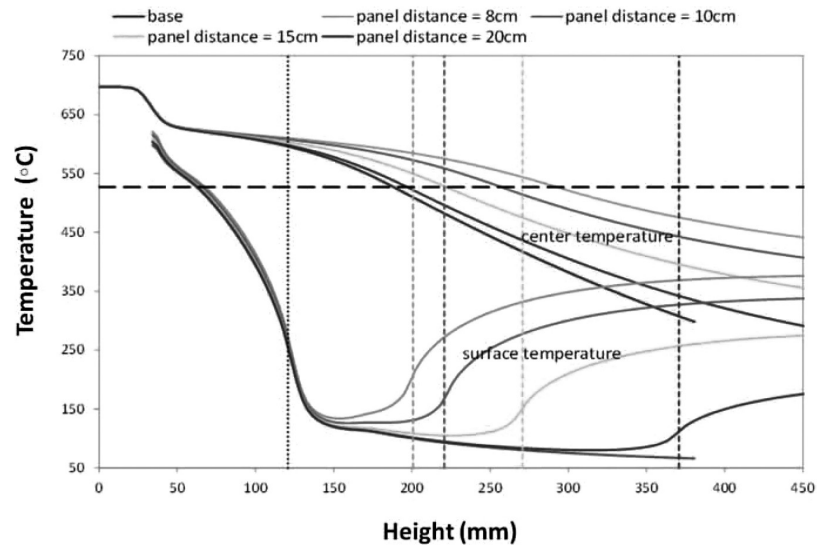

Figure 8: Temperature changes for the surface and center of the billet for different places of the panel of the $762 \mathrm{~mm}$ billet at the casting velocity of $2.1 \mathrm{~cm} / \mathrm{min}$

the velocity of $2.1 \mathrm{~cm} / \mathrm{min}$. Similar studies carried out for the billets with a diameter of $508 \mathrm{~mm}$ reveal that if we want to keep the pool depth below $0.5 R$, the casting velocities of $2.4 \mathrm{~cm} / \mathrm{min}$ or $3.0 \mathrm{~cm} / \mathrm{min}$ are suitable and the panel distances should be at least $7 \mathrm{~cm}$ and $5 \mathrm{~cm}$ from the bottom of the mold. For the billets with a diameter of $254 \mathrm{~mm}$, the suitable casting velocity is less than $6.0 \mathrm{~cm} / \mathrm{min}$ and the panel distance is $5 \mathrm{~cm}$.

The next parameter for removing the water is the temperature distribution after the water removal from the surface of the billet. The results for the casting velocity of $2.1 \mathrm{~cm} / \mathrm{min}$ and the $762 \mathrm{~mm}$ billet are presented in Figure 8. As a result of the reduction in the cooling rate for the surface of the billet, the surface temperature is increased if the water is removed from the surface of the billet. The temperature difference between the surface and the center is reduced and this difference is lower than in the case when there is no water removal. On the other hand, when a water removal occurs, the surface temperature at the location of the panel is not reduced, but it even increases. The trend of the changes in the temperatures of the surface and the center of the billet is such that the overall temperature gradient between the surface and the center decreases. This can greatly reduce the stress exerted on the billet center that can cause hot tearing.

To obtain more accurate observations of the effect of the water removal on the temperature gradient at the bottom of the pool, the plots in Figure 9 were drawn. In these plots, the temperature distribution in the radial direction is shown at the bottom of the pool. As seen in all the cases, the temperature in the center is equal to the solidus temperature and by increasing the panel distance, the surface temperature decreases and this temperature is similar to the situation of no water removal.

A large-freezing-range alloy promotes hot tearing given that such an alloy is for a longer time in a vulnerable state, in which thin liquid films form between the dendrites. At the final stage of the solidification $\left(f_{S}>\right.$ 


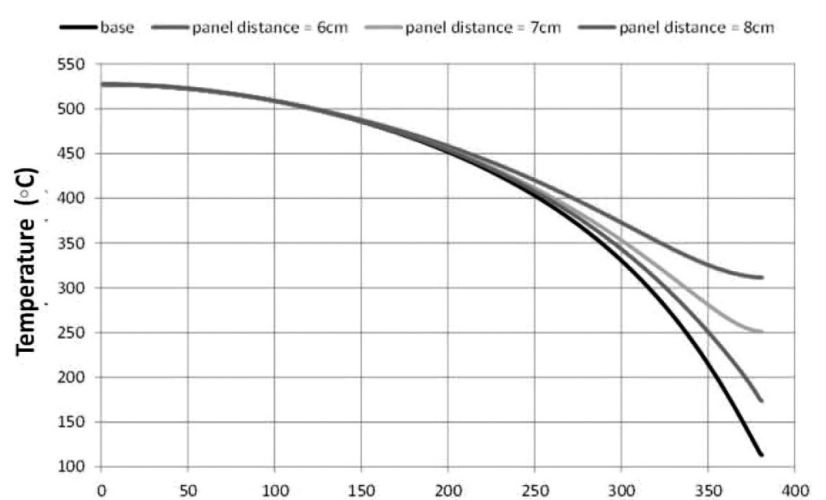

(a)

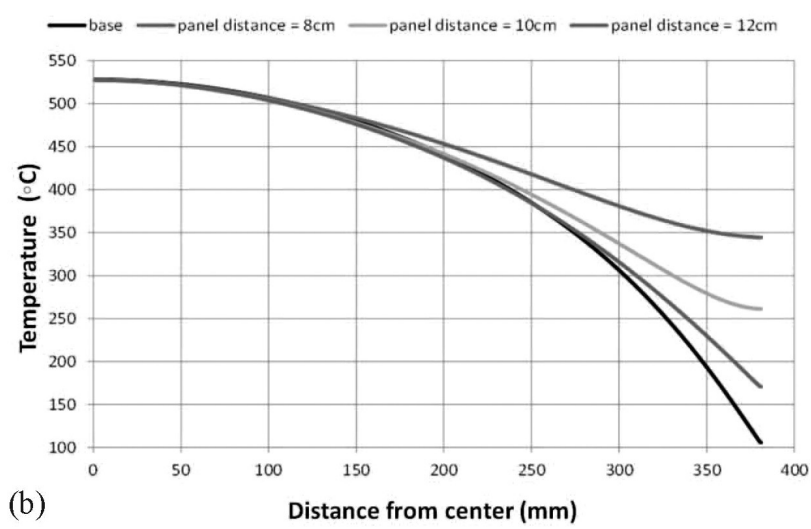

Figure 9: Temperature changes from the billet surface to the center at the end of the melt laver for different places of removing the water from the surface of the $762 \mathrm{~mm}$ billet at casting velocities of: a) $2 / 1$ $\mathrm{cm} / \mathrm{min}$ and b) $1 / 8 \mathrm{~cm} / \mathrm{min}$

0.9), only the solid-state creep can compensate for the solidification shrinkage and thermal stresses ${ }^{10}$. The strains and strain rates in the mushy zone increase if the cooling rate increases at the solid fraction equal to 0.95 in the center of the billet, which is plotted for three casting velocities and for different panel positions. In addition, by increasing the casting velocity, the panel-position (from the bottom of the mold) cooling rate increases and the use of the panel has a remarkable effect on the magnitude of the cooling rate in the critical solid fraction.

An additional reduction in the range of water cooling appears for the temperature gradient and cooling rate at the bottom of the pool. However, this position causes an increase in the pool depth and the mushy-zone thickness, so the place of the panel should be an optimized position. In this respect, the removal places of $7 \mathrm{~cm}$ and $10 \mathrm{~cm}$ are detected as suitable for $2.1 \mathrm{~cm} / \mathrm{min}$ and $1.8 \mathrm{~cm} / \mathrm{min}$, respectively, for the $762 \mathrm{~mm}$ billets as they cause minimum thermal gradients between the bottom of the pool and the surface. With the same calculation for the $508 \mathrm{~mm}$ billets, the places of the water removal of $5 \mathrm{~cm}$ and $7 \mathrm{~cm}$ can also be obtained for the casting velocities of $2.4 \mathrm{~cm} / \mathrm{min}$ and $3.0 \mathrm{~cm} / \mathrm{min}$, respectively. Finally, for the $254 \mathrm{~mm}$ billets, the place of the water

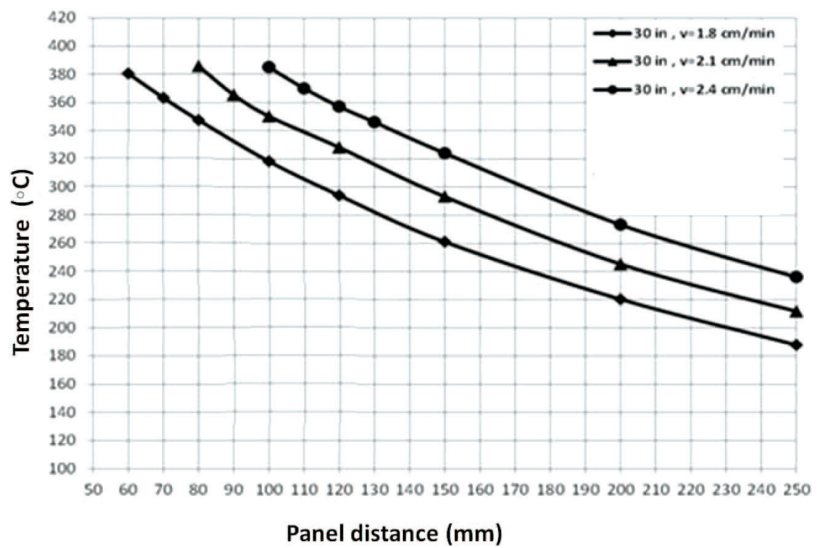

Figure 10: Differences in the temperature average of $762 \mathrm{~mm}$ billet in different casting velocities based on different places of removing water from the surface of the billet

removal of $5 \mathrm{~cm}$ was calculated for a casting velocity between $4.8 \mathrm{~cm} / \mathrm{min}$ and $5.4 \mathrm{~cm} / \mathrm{min}$.

It is necessary to remove the residual stresses from the heat treatment so as to produce an aluminum cast part at a temperature of $343{ }^{\circ} \mathrm{C}$; this temperature is $404{ }^{\circ} \mathrm{C}$ for alloy $2024 \mathrm{DC}$ cast in this research and the time for the heat treatment is $2-3 \mathrm{~h}$, as shown in Figure 10. With the increasing casting velocities, the billets do not have enough time for cooling and the average temperature difference increases at different casting velocities. These results were obtained to optimize the conditions for $10 \mathrm{~mm}$ and $762 \mathrm{~mm}$ billets. The average temperature of the surface and the center is between $320-380{ }^{\circ} \mathrm{C}$, which is less than the preferred temperature for alloy 2024. However, at this temperature, it is possible to remove the residual stresses and reduce the overall heat-treatment time.

\section{CONCLUSION}

In this survey, the modeling results of the water-removal method involving DC-cast billets of the 2024 alloy were investigated and compared with the results obtained with a simulation. Given that water removal causes an increase in the pool depth and expands the mushy zone, it is better to use a low casting velocity, at which the pool depth and mushy-zone thickness are small. On the other hand, as the important tasks of water removal are, firstly, to decrease the temperature gradient and the cooling rate or the strain rate at the bottom of the pool and, secondly, increase the temperature in the billet, it is necessary to decrease the water-cooling zone in order to be close to the above aims. Therefore, the water-cooling zone should be reduced, which causes an increase in the pool depth and the thickness of the mushy zone. Then, according to the points discussed, an optimized middle status should be selected. In this status, the casting velocities of $1.8 \mathrm{~cm} / \mathrm{min}$ or $2.1 \mathrm{~cm} / \mathrm{min}$ for the water-removal place of $7 \mathrm{~cm}$ and $10 \mathrm{~cm}$, respectively, 


\section{A. H. MEYSAMI et al.: MODELING OF WATER REMOVAL IN DIRECT-CHILL CASTING OF ALUMINUM-ALLOY BILLETS}

are used for casting $762 \mathrm{~mm}$ billets. For $508 \mathrm{~mm}$ billets, the casting velocity is $2.4 \mathrm{~cm} / \mathrm{min}$ and $3.0 \mathrm{~cm} / \mathrm{min}$ and the water-removal place is $7 \mathrm{~cm}$ and $5 \mathrm{~cm}$, respectively. For $254 \mathrm{~mm}$ billets, the casting velocity of $4.8 \mathrm{~cm} / \mathrm{min}$ and $6 \mathrm{~cm} / \mathrm{min}$ and the water-removal place of $5 \mathrm{~cm}$ are recognized as suitable casting conditions.

Using the parameters mentioned in the paragraph above, the highest surface temperature is about $320-380$ ${ }^{\circ} \mathrm{C}$, which is lower than the heat required for removing the residual stresses from alloy $2024\left(404{ }^{\circ} \mathrm{C}\right)$; but it seems that in the temperature range above, we can remove a considerable amount of residual stresses. Using another strategy, we can position the induction coils during the passing of the billet to bring them to the desired temperature, thereby saving enormous energy and removing the residual stresses that can lead to a distortion in the billet.

\section{Acknowledgment}

This work was supported by the Golpayegan University of Technology as an internal research project of 2017.

\section{Nomenclature}

Specific heat at constant pressure $\quad c_{\mathrm{p}}$

Gravity g

Enthalpy $\quad \mathrm{H}$

Kelvin K

Pressure $P$

Source term $S$

Time $\mathrm{t}$

Temperature $T$

Ref. temperature $\quad T_{0}$

Radial speed $\quad v_{\mathrm{r}}$

Axial speed $\quad v_{z}$

Watt W

Viscosity $\quad \mu$

Density $\rho$

Coefficient of thermal expansion $\quad \alpha$

\section{REFERENCES}

${ }^{1}$ P. P. Zeigler, Method of Continuous Casting, US patent, 2705335, 1955
${ }^{2}$ T. C. Zinniger, Direct Chill Casting Method with Coolant Removal, US patent, 4237961, 1980

${ }^{3}$ E. W. Reeves, R. Womack, W. J. Fenton, J. Mcdermott, J. Boorman, Method and Apparatus for Removal of Cooling Water from Ingots by Means of Water Jets, US patent, 2009/0301683, 2009

${ }^{4}$ E. Gervais, H. Levert, P. Chollet, Method for the Continuous Casting of Metal Ingots or Strips, US patent, 3891024, 1975

${ }^{5}$ C. Devadas, J. F. Grandfield, Experiences with Modelling DC Casting of Aluminum, in Proceedings of the $120^{\text {th }}$ TMS Annual Meeting Light Metals, TMS Annual Meeting: TMS (The Minerals, Metals \& Materials Society), 1990, 883-892

${ }^{6}$ D. G. Eskin, Physical Metallurgy of Direct Chill Casting of Aluminum Alloys, CRC Press, FL, 2008, 63

${ }^{7}$ W. Schneider, E. K. Jensen, Investigations about Starting Cracks in DC Casting of 6063 Type Billets, Part I: Experimental Results, Essential Readings in Light Metals, The Minerals, Metals \& Materials Society (TMS), 3 (1990), 743-748, doi:10.1002/ 9781118647783.ch94

${ }^{8}$ M. Rappaz, J. M. Drezet, M. Gremaud, A New Hot Tearing Criterion, Metall. Mater. Trans. A, 30 (1999) 1, 449-455, doi:10.1007/ s11661-999-0334-Z

${ }^{9}$ P. Barral, P. A. Quintela, Numerical method for simulation of thermal stresses during casting of aluminum slabs, Comput. Methods Appl. Mech. Engrg., 178 (1999) 1, 69-88, doi:10.1016/S0045-7825(99) 00005-5

${ }^{10}$ W. H. Suyitno, L. Kool, Hot tearing criteria evaluation for direct chill casting of an Al-4.5pct Cu alloy, Metall. Mater. Trans. A, 36 (2005) 1, 1537-1546, doi:10.1007/s11661-005-0245-6

${ }^{11}$ N. Hatami, R. Babaei, M. Dadashzadeh, Modeling of hot tearing formation during solidification, J. Mater. Process. Technol., 205 (2007) 1, 506-513, doi:10.1016/j.jmatprotec.2007.11.260

${ }^{12}$ M. Lalpoor, D. G. Eskin, L. Katgerman, Cold-cracking assessment in AA7050 billets during direct-chill casting by thermomechanical simulation of residual thermal stresses and application of fracture mechanics, Metall. Mater. Trans. A, 403 (2009)1, 304-313, doi:10.1007/s11661-009-0031-y

${ }^{13}$ Y. Xu, J. C. Wang, S. J. Guo, X. T. Li, G. X. Xue, Effects of WaterRestricted Panel on the Casting Process of High Strength Aluminum Alloy Ingots, Journal of Materials Processing Technology, 211 (2011) 1, 78-83, doi:10.1007/s11831-014-9100-5

${ }^{14}$ V. R. Voller, C. A. Prakash, Fixed grid numerical modeling methodology for convection-diffusion mushy region phase change problems, Int. J. Heat Mass Transfer, 30 (1978) 1, 1709-1719

${ }^{15}$ C. J. Vreeman, J. D. Schloz, M. J. M. Krane, Direct Chill Casting of Aluminum Alloys, Modeling and Experiments on Industrial Scale Ingots, Journal of Heat Transfer, Transactions of the ASME, 124 (2002) 5, 947-953, doi:10.1115/1.1482089

${ }^{16}$ F. Grandfield, L. Wang, Application of mathematical models to optimization of cast start practice for DC cast extrusion billets, Light Metals 2004, $1^{\text {st }}$ ed., Metals \& Materials Society (TMS), 2004, 685-690 